\title{
UTILIZATION OF APPLE POMACE COEXTRUDED WITH CORN GRITS IN SPONGE CAKE CREATION
}

\author{
Aleksandra M. Torbica*1, Jelena M. Tomić ${ }^{1}$, Danica M. Savanović ${ }^{2}$, Biljana S. Pajin ${ }^{3}$, Jovana S. \\ Petrović ${ }^{3}$, Ivana S. Lončarević ${ }^{3}$, Aleksandar Z. Fišteš ${ }^{3}$, Karolina A. Mocko Blažek ${ }^{1}$ \\ ${ }^{1}$ University of Novi Sad, Institute of Food Technology, 21000 Novi Sad, Bulevar cara Lazara 1, Serbia \\ ${ }^{2}$ University of Banja Luka, Faculty of Technology, 78000 Banja Luka, Bulevar vojvode Stepe \\ Stepanovića 73, Bosnia and Herzegovina \\ ${ }^{3}$ University of Novi Sad, Faculty of Technology, 21000 Novi Sad, Bulevar cara Lazara 1, Serbia
}

\author{
*Corresponding author: \\ Phone: +381214853625 \\ Fax: +38121450725 \\ E-mail address: aleksandra.torbica@fins.uns.ac.rs
}

\begin{abstract}
Apple pomace, a by-product that remains after extraction of juice from fruit, is a good source of dietary fibre, minerals and different phytochemicals such as phenolic acids. Although the valorization of apple pomace as a bakery ingredient was performed by several authors, there is a lack of information on attempts of incorporation of apple by-products in the form of coextrudates with corn grits (CAPCG). In this study, sponge cakes were created with apple pomace coextruded with corn grits in the ratio of $45: 55$ by partial replacing wheat flour with coextrudate in the formulation at $10 \%$, $20 \%$ and $30 \%$ level. With the increase in the proportion of coextruded particles, the farinographic characteristics of dough samples showed an increase in water absorption and dough development time due to larger particles of coextrudates, and loss of dough elasticity. Consequently, the cake specific volume decreased over the range between $3.6-14.2 \%$, but only the substitution level of $30 \%$ yielded an increase in cake firmness after $1 \mathrm{~h}$ of cooling and after $24 \mathrm{~h}$ of storage. The estimation of sponge cake sensory properties using the hedonic scale from 1 to 9 showed that the most acceptable texture was found in the control sample, whereas all sponge cakes with CAPCG had significantly higher acceptance of odour and taste in comparison to the control cake. From the nutritional point of view, sponge cakes substituted with CAPCG showed higher total dietary fibre content than the control wheat sponge cake.
\end{abstract}

Key words: fruit by-product, wheat, substitution, dough properties, texture, fibre

\section{INTRODUCTION}

Dietary guidelines recommend increased consumption of fibre which consequently influenced the occurrence of various value-added food products in the market. The health benefits of dietary fibre consumption are well documented. Namely, the positive effects of fibre are related to the blood glucose and cholesterol atenuation, protection against cardiovascular diseases, regulation of intestinal function and promotion of gut health (Ktenioudaki and Gallagher, 2012). Most studies have been carried out on the fortification of food products with dietary fibre, especially on the fortification of bakery product as a most consumed products by the majority of the population. Although bakery products are a convenient medium for the provision of nutritional requirements for dietary fibre, there are some detrimental effects on the physico-chemical and rheological properties of these products. Additionally, incorporation of high levels of fibres often leads to impaired sensory quality of baked product in terms of volume, colour and taste (Sievert et al., 
1990). Considerable efforts have been made to harmonize health benefits and sensory properties of newly created food products. Currently, the most widely consumed products with higher levels of fibres are those originated from cereals. Among them, wheat and oat based products gained special position. Besides the cereal-derived fibres, nutritional trends imposed the need for a new source of dietary fibres; therefore the implementtation of fibres originating from fruits has gained popularity. There are many studies which are focused on utilization of fruit and vegetable fibres in bakery products. These are either commercial fibres or fibres derived from by-products of plant food processing (Ktenioudaki and Gallagher, 2012). Fruit by-products, especially those that underwent thermal treatment, are suitable for implementation in bakery applications owing to their specific flavour, generated from non-enzymatic browning reactions, including caramelized sugar aromas (Bchir et al., 2014). Apple pomace, a by-product that remains after extraction of juice from fruit, is mainly used as animal feed. It is a good source of dietary fibre with a well-balanced proportion of soluble and insoluble fibre fractions (O'Shea et al., 2012). These fibres are mostly composed from pectin, cellulose, hemicelluloses, lignin and gums (Bhushan et al., 2008).

Apple pomace is a valuable source of minerals such as calcium, magnesium, zinc, iron, and copper as well a good source of different phytochemicals such as phenolic acids (Kohajdová et al., 2014). Valorization of apple pomace as a bakery ingredient was performed by several authors. Sudha et al. (2007) showed that substitution of wheat flour with apple pomace had significant influence on elastic and pasting properties of the wheat flour dough depending on the level of substitution. The alteration of rheological properties as an influence of fruit by-products addition was observed by Ktenioudaki et al. (2013). Regarding the sensory properties, cakes prepared from $25 \%$ of apple pomace-wheat flour blend besides satisfying the nutritional aspect exhibited high acceptable quality (Sudha et al., 2007). As the pomace level increased beyond 10\% (Sudha et al., 2007; Masoodi et al., 2002), the quality of the final product deteriorated only in terms of volume and darker colour, while pleasant flavour was registrated. In general, the influence of apple pomace incorporation on rheological properties and quality of final product is highly determined by the level of incorporation as well as by the particle size of the used fibres (Ktenioudaki and Gallagher, 2012).

Although there are some reports about the incorporation of dietary fibre in sweet baked goods (Namir et al., 2015; Majzoobi et al., 2016; Quiles et al., 2018), there has been a scarcity of reports on the use of apple by-products in the form of coextrudates with corn grits as a source of dietary fibres in bakery products. Therefore, the purpose of this study was to partially replace wheat flour in the formulation of sponge cake with apple pomace coextruded with corn grits in the ratio of $45: 55$ and to measure the nutritional and sensory properties of the resulting cakes.

\section{MATERIALS AND METHODS}

In this study, fine white wheat flour for cake production $(0.45 \%$ ash content) purchased from the local supermarket (Danubius, Serbia) was used as raw material for the sponge cake production.

Apple pomace coextruded with corn grits was generously supplied by Josip Juraj Strossmayer University of Osijek, Croatia.

The preparation included homogenization of dried apple pomace and corn grits in proportion of 45:55. Prepared blends with $15 \%$ of moisture content was extruded in a laboratory single screw extruder 19/20DN (Brabender, Germany), at temperature profile $135 / 170 / 170{ }^{\circ} \mathrm{C}$, using a screw with compression ratio $4: 1$ and die with $4 \mathrm{~mm}$ diameter. The obtained extrudates were air-dried overnight and milled in a laboratory mill prior the further use. Apple pomace coextruded with corn grits (CAPCG) was used to replace $10 \%, 20 \%$, and $30 \%$ of wheat flour.

\section{Particle size distribution}

The particle size distribution (PSD) of wheat flour and CAPCG was determined 
using a laser diffraction particle size analyzer (Mastersizer 2000, Malvern Instruments, UK). The Scirocco dispersion unit was used for dispersing powders in the air. The results were quantified as the volume-based PSD by means of the Mastersizer 2000 software. PSD was described by the volume mean diameter $\mathrm{D}[4,3]$, and parameters $d(0.1), d(0.5)$, and $d(0.9)$ representing the particle sizes where 10,50 or $90 \%$ of the total particle volume was formed by particles smaller than this size, respectively.

\section{Rheological measurements}

The effects of corn grits coextruded with apple pomace on dough characteristics (water absorption of mixture, dough development time, dough resistance and degree of softening) were evaluated by farinograph according to the Hungarian standard method MSZ 6369/6 (Hungarian Standard, 1988).

\section{Preparation of sponge cake}

Sponge cake formula consisted of $100 \mathrm{~g}$ of wheat flour, $100 \mathrm{~g}$ of sugar, $100 \mathrm{~g}$ of whole egg, $4 \mathrm{~g}$ of baking powder and $20 \mathrm{~g}$ of water. Apple pomace coextruded with corn grits was incorporated into sponge cakes at 3 levels $(10 \%, 20 \%$, and $30 \%$ $\mathrm{w} / \mathrm{w}$ ) by replacing equivalent amount of wheat flour in the cake mixture. The first step involves mixing egg whites and egg yolks separately with an equal amount of sugar. The remaining dry ingredients (wheat flour and sodium bicarbonate) were added after the coupling of eggs with water. Cake batter $(60 \mathrm{~g})$ was poured into a Teflon baking mould of $12 \mathrm{~cm}$ diameter and baked in a preheated electrical baking oven (MIWE condo, Arnstein, Germany) at $180{ }^{\circ} \mathrm{C}$ for $20 \mathrm{~min}$. Then, the cakes were removed from the oven and cooled at ambient temperature for $1 \mathrm{~h}$. The cakes were sealed in polyethylene bags and kept at ambient temperature for further experiments.

\section{Chemical composition}

Moisture content, protein, fat, total dietary fibre content and total sugars content of cakes were determined according to the Association Official of Analytical Chemists (AOAC, 2000) methods 925.10, 950.36,
935.38, 985.29 and according to standard AACC methods 80-68. Total starch content was determined according to ISO standards 10520:1997. Two replicates were performed for each analysis.

\section{Sponge cake quality assessment}

The volume of sponge cakes was determined using a laser measuring device VolScan Profiler 600 (Stable Micro Systems, England). Laser step was set to 4 $\mathrm{mm}$ and rotation speed was set to $1 \mathrm{rps}$. Specific volume was calculated as the volume to mass ratio $(\mathrm{ml} / \mathrm{g})$.

Measurement of sponge cakes colour was performed by a Chroma Meter CR-400 (Konica Minolta Co., Ltd., Osaka, Japan. The colour of crust and crumb were measured at five points. CIE $L^{*}$ (lightness), CIE $a^{*}\left(+a^{*}=\right.$ redness, $-a^{*}=$ greenness $)$ and $\mathrm{CIE} b^{*}\left(+b^{*}=\right.$ yellowness, $-b^{*}=$ blueness) were read using a D65 light source and the observer angle of $2^{\circ}$.

Texture profile analysis (TPA) was performed using TA.XT Plus Texture Analyser (Stable Micro Systems, Godalming, UK). Determination of firmness was performed on four cube-shaped $(3.5 \mathrm{~cm})$ samples taken from the central crumb of cakes. The test speed was $1.7 \mathrm{~mm} \mathrm{~s}^{-1}$, and maximum strain was $40 \%$ of the original cube height.

\section{Sensory analysis}

The sensory analysis was performed with twelve trained sensory panellists ( 9 female and 3 male, aged 25-50 years), experts in sensory profiling of different types of bakery and confectionery products. Prior the analysis, the panellists were introduced with product characteristics throughout several sessions on commercial products, the most similar to the tested sponge cakes. Evaluation of sponge cake's crust and crumb colour, texture, odour, taste and overall acceptability was performed by using 9-point hedonic scale $(1=$ dislike extremely to $9=$ like extremely).

\section{Data analysis}

Analysis of variance (ANOVA) and $\mathrm{Fi}-$ sher's least significant differences test were applied at $5 \%$ significance level to 
determine differences among the analyzed samples using Statistica 13.3 software (TIBCO Software Inc., USA, 2016).

\section{RESULTS AND DISCUSSION}

\section{Particle size distribution}

Particle size parameters of wheat flour and CAPCG are presented in Table 1. It can be noticed that CAPCG powder in generally had larger particle sizes comparing to wheat flour, with significantly higher values of all particle size parameters $(d(0.1), d(0.5), d(0.9)$ and $D[4,3])$. Additionally, CAPCG particles were more uniform in size (much closer to narrow distribution) than the particles of wheat flour. The largest percentage of wheat flour particles $(79.26 \%)$ ranged in interval from 25 to $200 \mu \mathrm{m}$, whereas the largest percentage of CAPCG particles (80.22\%) was in interval $100-1000 \mu \mathrm{m}$.

\section{Farinographic characteristics of dough}

The farinographic characteristics of dough samples containing different levels of CAPCG are given in Figure 1. Each rheological parameter showed characteristic trend. Water absorption, as the most important parameter for dough handling properties, increased with rising levels of wheat flour substitution due to higher content of fibres and extruded particles (from $56.2 \%$ to $64.2 \%$ ). The development time also increased (from $1.2 \mathrm{~min}$ to $4.3 \mathrm{~min}$ ) as a consequence of the higher number of larger particles and a reduction in their total specific surface area. The loss of dough elasticity, due to the incorporation of solid non-elastic particles of coextrudate and disruption of internal gluten structure, is clearly visible by the decrease in the width of the farinograph curve.

\section{Chemical composition of sponge cakes}

By chemical composition (Table 1), the most significant difference between control and flour-replaced cakes was obtained for fibre content. Addition of CAPCG to sponge cake provoked a pronounced increment in total dietary fibre (TDF) content. According to the European Food Safety Authority (EFSA, 2010), the currently recommended fibre intakes for adults range from 25 to $30 \mathrm{~g} /$ day for women and men, respectively. Control wheat sponge cake and all sponge cakes produced with apple pomace coextruded with corn grits showed well balanced ratio of IDF/SDF, and it was nutritionally beneficial.

\section{Structure development in sponge ca- kes}

Typical structure of sponge cake produced by standard recipe was modified by the addition of coextruded apple pomace with corn grits (CAPCG) (Figure 2). The total specific area of particles decreased due to the substitution of flour with larger coextruded particles. This influenced a variation in the distribution of the air cells, as can be seen in Figure 3. There are more cells of larger diameter in cake crumb with addition of CAPCG than in the crumb of control cake. With the increase in the proportion of coextruded particles, the cake specific volume decreased in the range of 3.6 to $14.2 \%$, but in practice it does not represent a major change (Table 2).

Similar results were observed by Namir et al. (2015) who studied the quality of low fat cake by incorporating tomato pomace as fat substitute. The reduction of cake specific volume could be due to the dilution of gluten while occurrence of larger cells and less uniformity of the crumb structure could be due to destabilization of the gluten starch matrix by larger coextruded particles (Kohajdová et al., 2014).

\section{Volume, texture and colour properties of sponge cakes}

The results for specific volume were in accordance with the obtained firmness values; firmness is a relevant indicator of the texture properties of the produced sponge cakes. It was observed that only at $30 \%$ substitution of wheat flour with CAPCG, cake firmness increased after $1 \mathrm{~h}$ of cooling and $24 \mathrm{~h}$ of storage (Figure 3 ).

This probably arose from a greater degree of cohesiveness of cakes and greater mechanical strength of the coextruded particles.

The colour parameters were highly influenced by the addition of CAPCG. Significant differences were observed bet- 
ween the crust and crumb of the control sponge cake and the cakes with addition of CAPCG (Table 3).

As expected, with increasing level of CAPCG, the crust and crumb of sponge cakes became darker (lower $L^{*}$ ) due to the original colour of used substituent which is mainly associated to Maillard and caramelization reactions during extrusion and baking process.

Table 1.

Particle size parameters of wheat flour and apple pomace coextruded with corn grits

\begin{tabular}{lcccc}
\hline Sample & $d(0.1)$ & $d(0.5)$ & $d(0.9)$ & $D[4,3]$ \\
\hline Wheat flour & 15.66 & 64.41 & 140.44 & 71.70 \\
CAPCG & 59.03 & 325.05 & 785.73 & 381.98 \\
\hline
\end{tabular}

Table 2

Chemical composition of sponge cakes

\begin{tabular}{lcccc}
\hline & Control & $\mathbf{1 0 \%}$ CAPCG & $\mathbf{2 0 \%}$ CAPCG & 30\% CAPCG \\
\hline Moisture (\%) & $22.58 \pm 0.07^{\mathrm{a}}$ & $22.51 \pm 0.05^{\mathrm{ab}}$ & $22.40 \pm 0.04^{\mathrm{b}}$ & $23.43 \pm 0.05^{\mathrm{b}}$ \\
Protein (\%) & $7.87 \pm 0.01^{\mathrm{b}}$ & $7.43 \pm 0.04^{\mathrm{c}}$ & $8.34 \pm 0.05^{\mathrm{a}}$ & $7.17 \pm 0.04^{\mathrm{d}}$ \\
Fat (\%) & $4.05 \pm 0.08^{\mathrm{a}}$ & $3.66 \pm 0.02^{\mathrm{b}}$ & $3.92 \pm 0.04^{\mathrm{a}}$ & $3.34 \pm 0.04^{\mathrm{c}}$ \\
Sugars (\%) & $32.67 \pm 0.08^{\mathrm{b}}$ & $35.74 \pm 0.13^{\mathrm{a}}$ & $35.58 \pm 0.04^{\mathrm{a}}$ & $35.84 \pm 0.11^{\mathrm{a}}$ \\
Total starch (\%) & $22.47 \pm 0.17^{\mathrm{a}}$ & $21.74 \pm 0.17^{\mathrm{b}}$ & $21.89 \pm 0.00^{\mathrm{b}}$ & $19.24 \pm 0.00^{\mathrm{c}}$ \\
TDF (\%) & $2.1 \pm 0.03^{\mathrm{d}}$ & $2.59 \pm 0.02^{\mathrm{c}}$ & $3.08 \pm 0.05^{\mathrm{b}}$ & $3.57 \pm 0.07^{\mathrm{a}}$ \\
IDF (\%) & $1.8 \pm 0.08^{\mathrm{c}}$ & $2.10 \pm 0.10^{\mathrm{bc}}$ & $2.39 \pm 0.14^{\mathrm{ab}}$ & $2.69 \pm 0.17^{\mathrm{a}}$ \\
SDF (\%) & $0.30 \pm 0.06^{\mathrm{c}}$ & $0.49 \pm 0.08^{\mathrm{bc}}$ & $0.69 \pm 0.10^{\mathrm{ab}}$ & $0.88 \pm 0.10^{\mathrm{a}}$ \\
IDF/SDF & $6.00^{\mathrm{a}}$ & $4.29^{\mathrm{ab}}$ & $3.46^{\mathrm{ab}}$ & $3.06^{\mathrm{b}}$ \\
\hline
\end{tabular}

TDF: Total dietary fibre; IDF: Insoluble dietary fibre; SDF: Soluble dietary fibre

Results are expressed as means \pm standard deviations $(n=2)$. Values in rows with different letters are significantly different $(P<0.05)$

Table 3

Specific volume of sponge cake samples

\begin{tabular}{lccc} 
Sample & Volume $(\mathbf{m l})$ & Weight $(\mathbf{g})$ & Specific volume $(\mathbf{m l} / \mathbf{g})$ \\
\hline Control & $203.23 \pm 17.60^{\mathrm{a}}$ & $51.58 \pm 0.46^{\mathrm{a}}$ & $3.94 \pm 0.38^{\mathrm{a}}$ \\
$10 \%$ CAPCG & $197.29 \pm 3.48^{\mathrm{ab}}$ & $51.90 \pm 0.00^{\mathrm{a}}$ & $3.80 \pm 0.07^{\mathrm{ab}}$ \\
$20 \%$ CAPCG & $190.77 \pm 3.13^{\mathrm{ab}}$ & $51.63 \pm 0.18^{\mathrm{a}}$ & $3.70 \pm 0.07^{\mathrm{ab}}$ \\
$30 \%$ CAPCG & $175.01 \pm 5.63^{\mathrm{b}}$ & $51.85 \pm 0.21^{\mathrm{a}}$ & $3.38 \pm 0.12^{\mathrm{b}}$ \\
\hline
\end{tabular}

Results are expressed as means \pm standard deviations $(n=2)$. Values in columns with different letters are significantly different $(P<0.05)$

Table 4

Colour properties of sponge cake samples

\begin{tabular}{llcccc}
\hline Sample & & Control & 10\% CAPCG & 20\% CAPCG & 30\% CAPCG \\
\hline \multirow{2}{*}{$\mathbf{L}^{*}$} & Crust & $78.40 \pm 1.60^{\mathrm{a}}$ & $52.89 \pm 1.65^{\mathrm{b}}$ & $48.57 \pm 1.32^{\mathrm{c}}$ & $41.28 \pm 0.53^{\mathrm{d}}$ \\
& Crumb & $76.51 \pm 3.58^{\mathrm{a}}$ & $49.02 \pm 1.48^{\mathrm{b}}$ & $42.77 \pm 2.73^{\mathrm{c}}$ & $36.89 \pm 3.23^{\mathrm{d}}$ \\
\hline \multirow{2}{*}{$\mathbf{a}^{*}$} & Crust & $1.29 \pm 0.82^{\mathrm{d}}$ & $9.33 \pm 0.61^{\mathrm{c}}$ & $10.56 \pm 0.50^{\mathrm{b}}$ & $11.70 \pm 0.33^{\mathrm{a}}$ \\
& Crumb & $-1.70 \pm 0.47^{\mathrm{d}}$ & $7.81 \pm 0.35^{\mathrm{c}}$ & $10.49 \pm 0.49^{\mathrm{b}}$ & $12.18 \pm 0.90^{\mathrm{a}}$ \\
\hline \multirow{2}{*}{$\mathbf{b}^{*}$} & Crust & $31.10 \pm 1.16^{\mathrm{d}}$ & $28.15 \pm 0.96^{\mathrm{c}}$ & $25.85 \pm 1.07^{\mathrm{b}}$ & $21.53 \pm 0.46^{\mathrm{a}}$ \\
& Crumb & $23.90 \pm 1.44^{\mathrm{b}}$ & $28.98 \pm 0.40^{\mathrm{a}}$ & $27.78 \pm 1.57^{\mathrm{a}}$ & $25.34 \pm 2.42^{\mathrm{b}}$ \\
\hline
\end{tabular}

Results are expressed as means \pm standard deviations $(n=6)$. Values in rows with different letters are significantly different $(P<0.05)$ 

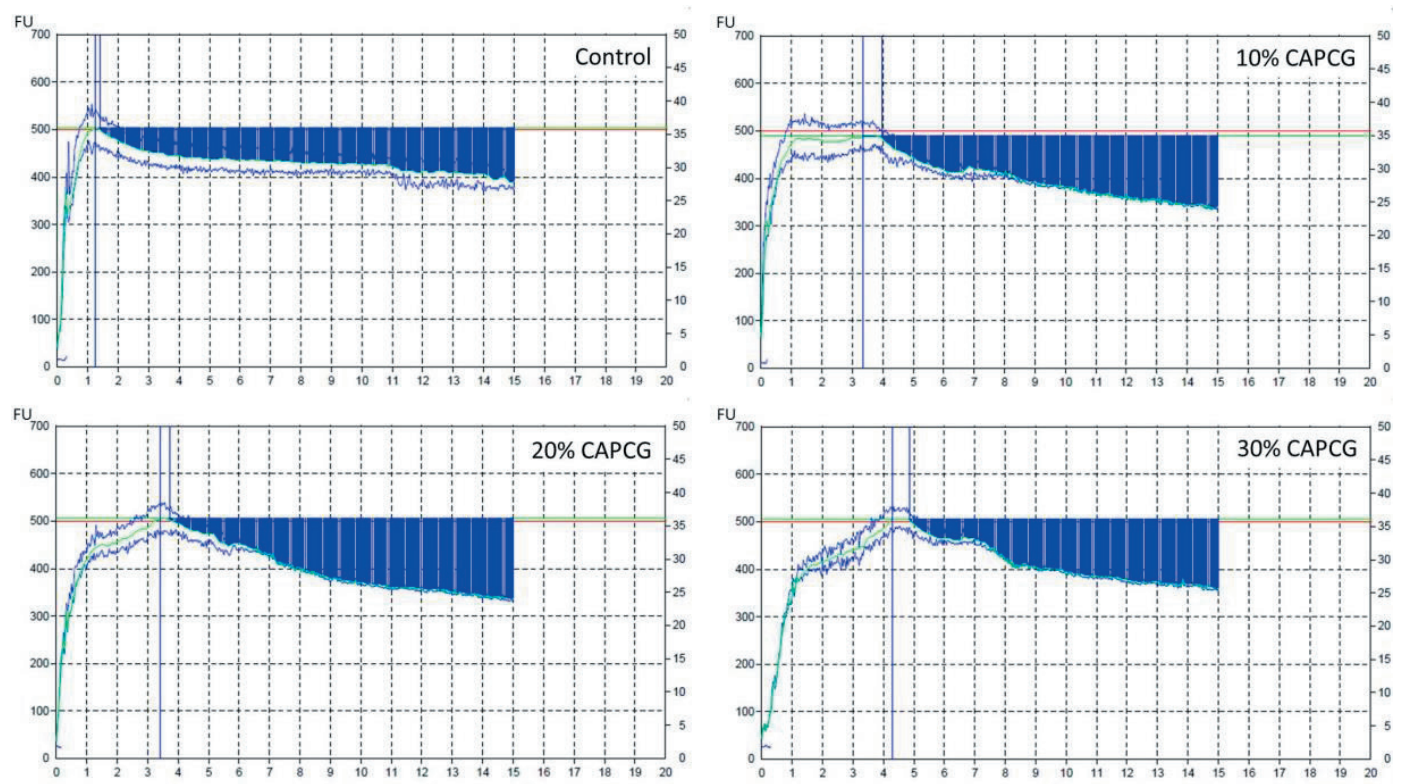

Figure 1. Farinograph curves of wheat dough supplemented with CAPCG; CAPCG was added at 10, 20 and $30 \%$ level (wheat flour basis)
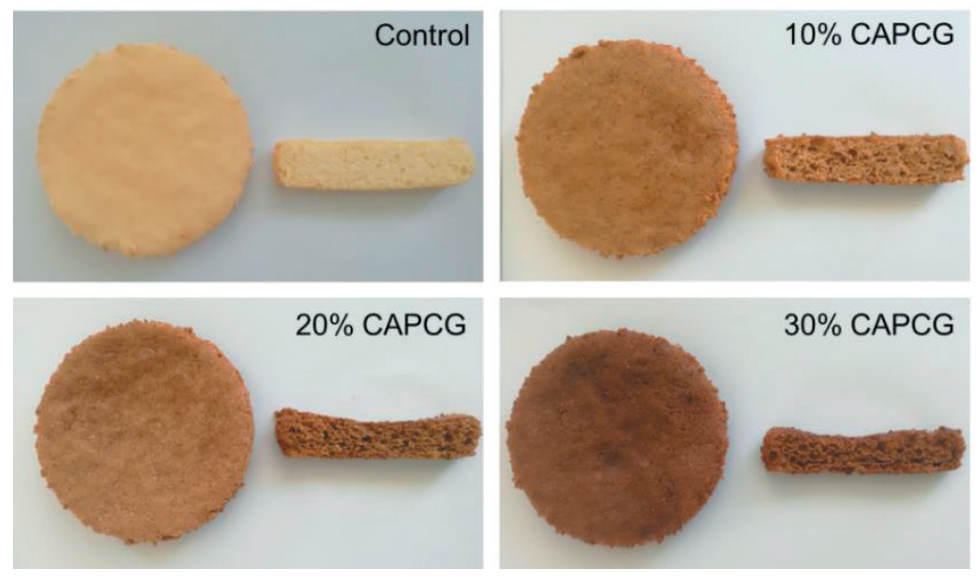

Figure 2. Surface and cross section of cakes prepared with the addition of CAPCG at different substitution levels

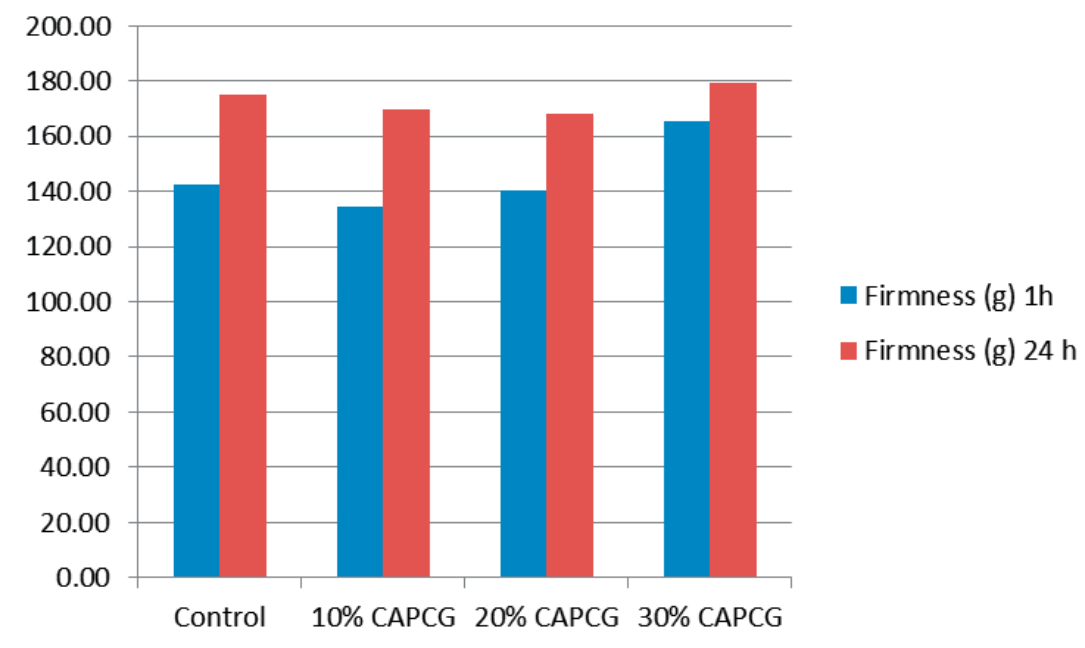

Figure 3. Textural properties of cakes prepared with the addition of CAPCG at different substitution levels concentrations $(0,10,20$ and $30 \%)$ of CAPCG 


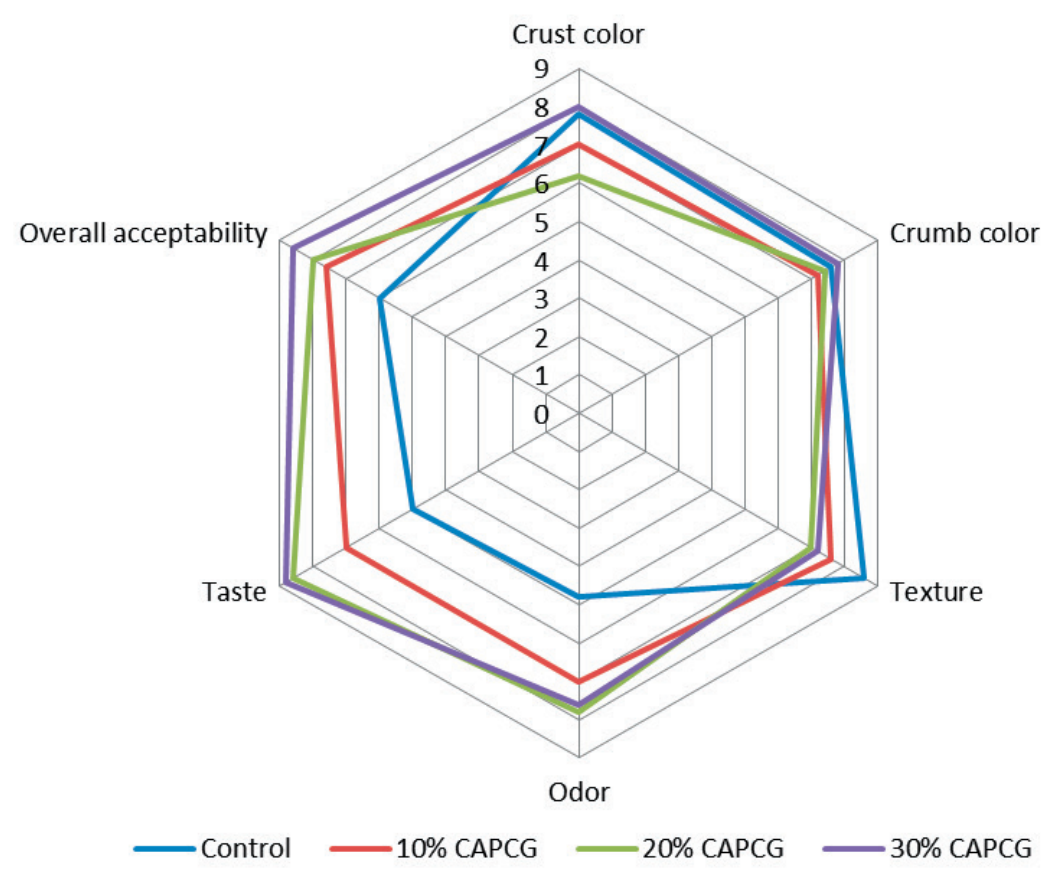

Figure 4. Sensory evaluation scores for cakes prepared with addition of CAPCG at different concentrations $(0,10,20$ and $30 \%)$

\section{Sensory evaluation}

The sensory evaluation of sponge cakes using the hedonic scale from 1 to 9 showed the subjective acceptability of the product and was not always in agreement with the values of the previously discussed objective physical indicators. The texture acceptance was the only attribute that was scored the highest for the control sample, and it decreased with the increased level of substitution by co-extruded particles.

Probably a big difference in the hardness of the particles in the blends influenced the lower acceptance of these cakes. With regard to odour and taste, the acceptance of flour-replaced cakes was significantly higher $(p<0.05)$ and it increased with the increase in the level of substitution of wheat flour with coextruded particles. The possible reason for this preference was the increased proportion of apple pomace and its pleasant flavour and taste enriched with a large number of products produced by Maillard's reactions in the extrusion process. Lastly, overall acceptance followed the same tendency as odour and taste.

\section{CONCLUSIONS}

The results from the present study clearly demonstrated that incorporation of apple pomace coextruded with corn grits at different levels strongly affected the physico-chemical and sensory properties of sponge cake. The addition of CAPCG had pronounced effects on dough rheological properties. Incorporation of CAPCG resulted in higher water absorption, loss of dough elasticity and prolonged dough development time. Consequently, the cake specific volume decreased in the range from 3.6 to $14.2 \%$, but only the level of $30 \%$ substitution of wheat flour with CAPCG influenced the increase in the cake firmness.

Besides the negative effect of CAPCG on cake texture, all sponge cakes with CAPCG had higher sensory evaluation scores in terms of odour, taste and overall acceptability in comparison to the control cake. From the nutritional point of view, sponge cakes produced with CAPCG were improved due to higher total dietary fibre content in comparison to the control wheat sponge cake. 


\section{ACKNOWLEDGEMENTS}

This paper is a result of the research within the project TR31007 financed by the Ministry of Education, Science and Technological Development, Republic of Serbia and the project 142-451-2445/2018 financed by the Provincial Secretariat for Science and Technological Development, Autonomous Province of Vojvodina, Republic of Serbia.

\section{REFERENCES}

1. AACC (2017). AACC Approved Methods of Analysis, $11^{\text {th }}$ Ed. 80-68.01 Determination of Reducing Sugars -Schoorl; AACC International, St. Paul, MN, USA (2017). Retrieved July 02, 2018 from

(https://aaccipublications.aaccnet.org).

2. AOAC (2000). Official Methods of Analysis, $17^{\text {th }}$ Ed. The Association of Official Analytical Chemists, Gaithersburg, MD, USA. Methods 925.10, 950.36, 935.38, 985.29.

3. Bchir, B., Rabetafika, H.N., Paquot, M., Blecker, C. (2014). Effect of pear, apple and date fibres from cooked fruit by-products on dough performance and bread quality. Food and Bioprocess Technology, 7 (4), 1114-1127.

4. Bhushan, S., Kalia, K., Sharma, M., Singh, B., Ahuja, P.S. (2008). Processing of apple pomace for bioactive Molecules. Critical Reviews in Biotechnology, 28, 285-296.

5. EFSA (2010). European Food Safety Authority, Scientific Opinion on Dietary Reference Values for carbohydrates and dietary fibre (2010). EFSA Panel on Dietetic Products, Nutrition, and Allergies. EFSA Journal 2010, 8(3),1462 [77 pp.]

6. Hungarian Standard (1988). Lisztvizsgálati módszerek. Vízfelvevő képesség és sütőipari érték. MSZ 6369/6.

7. ISO (1997). Determination of starch content, Ewers polarimetric method. ISO 10520 International Organization for Standardization, Geneva, Switzerland.

8. Kohajdová, Z., Karovičová, J., Magala, M., Kuchtová, V. (2014). Effect of apple pomace powder addition on farinographic properties of wheat dough and biscuits quality. Chemical $\mathrm{Pa}$ pers, 68 (8), 1059-1065.

9. Ktenioudaki, A., Gallagher, E. (2012). Recent advances in the development of high-fibre baked products. Trends in Food Science and Technology, 28 (1), 4-14.

10. Ktenioudaki, A., O'Shea, N., Gallagher, E. (2013). Rheological properties of wheat dough supplemented with functional by-products of food processing: Brewer's spent grain and apple pomace. Journal of Food Engineering, 116 (2), 362-368.

11. Majzoobi, M., Poor, Z.V., Jamalian, J., Farahnaky, A. (2016). Improvement of the quality of gluten-free sponge cake using different levels and particle sizes of carrot pomace powder. International Journal of Food Science and Technology, 51(6), 1369-1377.

12. Masoodi, F.A., Sharma, B., Chauhan, G.S. (2002). Use of apple pomace as a source of dietary fiber in cakes. Plant Foods for Human Nutrition, 57 (2), 121-128.

13. Namir, M., Suleiman, A.R., Hassanien, M.F.R. (2015). Characterization and functionality of alcohol insoluble solids from tomato pomace as fat substitute in low fat cake. Journal of Food Measurement and Characterization, 9 (4), 557563.

14. O'Shea, N., Arendt, E. K., Gallagher, E. (2012). Dietary fibre and phytochemical characteristics of fruit and vegetable by-products and their recent applications as novel ingredients in food products. Innovative Food Science and Emerging Technologies, 16, 1-10.

15. Quiles, A., Llorca, E., Schmidt, C., Reißner, A. M., Struck, S., Rohm, H., Hernando, I. (2018). Use of berry pomace to replace flour, fat or sugar in cakes. International Journal of Food Science and Technology, 53 (6), 1579-1587.

16. Regulation of Methods, 1988. Regulation of methods of physical and chemical analysis for quality control of grain, milling and bakery products, pasta and quickly frozen dough. In: Official Gazette of SFRJ, 74 - Pravilnik o metodama fizičkih i hemijskih analiza za kontrolu kvaliteta žita, mlinskih i pekarskih proizvoda, testenina i brzo smrznutih testa - Službeni list SFRJ, 74 (1988) (in Serbian).

17. Sievert, D., Pomeranz, Y., Abdelrahman, A. (1990). Functional properties of soy polysaccharides and wheat bran in soft wheat products. Cereal Chemistry, 67 (1), 10-13.

18. Sudha, M.L., Baskaran, V., Leelavathi, K. (2007). Apple pomace as a source of dietary fiber and polyphenols and its effect on the rheological characteristics and cake making. Food Chemistry, 104 (2), 686-692. 


\section{УПОТРЕБА ТРОПА ЈАБУКЕ КОЕКСТРУДИРАНОГ СА КУКУРУЗНОМ КРУПИЦОМ У КРЕИРАҢУ БИСКВИТНОГ КОЛАЧА}

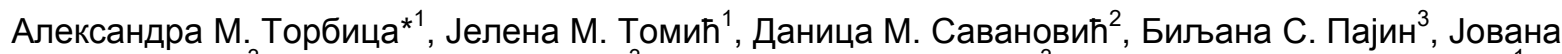
С. Петровић ${ }^{3}$, Ивана С. Лончаревић ${ }^{3}$, Александар 3. Фиштеш ${ }^{3}$, Каролина А. Моцко Блажек ${ }^{1}$

${ }^{1}$ Универзитет у Новом Саду, Научни институт за прехрамбене технологије у Новом Саду, 21000 Нови Сад, Булевар цара Лазара 1, Србија

${ }^{2}$ Универзитет у Бањој Луци, Технолошки факултет, 78000 Бања Лука, Булевар војводе Степе Степановића 73, Босна и Херцеговина

${ }^{3}$ Универзитет у Новом Саду, Технолошки факултет у Новом Саду, 21000 Нови Сад, Булевар цара Лазара 1, Србија

Сажетак: Троп јабуке је нуспроизвод који преостаје након екстракције сока из воћа, и добар је извор дијететских влакана, минерала и разних фритохемикалија, као што су фенолне киселине. Иако је валоризација тропа јабуке као пекарског састојка испитана од стране неколико аутора, не постоје информације о покушајима примене нуспроизвода јабуке у облику коекструдата са кукурузном крупицом (CAPCG). У овој студији креиран је бисквитни колач са тропом јабуке коекструдираног са кукурузном крупицом (у односу 45:55) тако што је пшенично брашно делимично супституисано (10\%, 20\% и 30\%) коекструдатом. Са повећањем удела коекструдираних честица, фаринографским мерењима узорака теста утврђено је повећање моћи упијања воде брашна, продужено време развоја теста и смањење еластичности теста. Последично је специфична запремина колача смањена за 3,6 до 14,2\%, али је само ниво супституције пшеничног брашна са 30\% CAPCG утицао на повећање чврстоће бисквитног колача након 1 часа хлађења и после 24 часа складиштења. Процена сензорских особина бисквитних колача помоћу хедонске скале од 1 до 9 показала је да је најприхватљивију текстуру имао контролни узорак, док су сви бисквитни колачи са CAPCG имали знатно већу прихватљивост мириса и укуса у односу на контролни колач. Са нутритивног аспекта, бисквитни колачи произведени са CAPCG имали су већи укупни садржај дијететских влакана у односу на контролни бисквитни колач од пшеничног брашна.

Кључне речи: нуспроизводи прераде воћа, пшеница, супституција, особине теста, текстура, влакна

Received: 28 September 2018

Received in revised form: 29 November 2018

Accepted: 10 December 2018 